\title{
Religion and Education in the Shadow of the European Court of Human Rights*
}

\author{
Effie Fokas
}

\section{Grassrootsmobilise; Hellenic Foundation for European and Foreign Policy (ELIAMEP); Hellenic Observatory, London School of Economics}

\begin{abstract}
This article presents a symposium on the "indirect effects" of the European Court of Human Rights jurisprudence on the place of religion in the educational sphere. The symposium showcases empirical research providing critical insight into how the Court's decisions may influence related domestic debates, raise public consciousness, and change how social actors perceive their rights and articulate their right claims in the area of religion and education. The research underpinning this symposium represents a clear departure from existing scholarship in this domain: it examines the impact of the Court not from the top-down (Court impact on states and their legislative frameworks) but from grassroots level upwards, in seeking to understand whether, how and to what extent Court decisions influence grassroots level actors' conceptions of their rights in the domain of religion and education and their efforts to secure new rights vis-à-vis their states.
\end{abstract}

The educational arena constitutes a critical and fraught juncture between religion and law. From questions of whether and how religion should be taught in public schools to whether a crucifix can be worn by students or displayed on a wall, the school has become a flashpoint for tensions between states and individual citizens, between secularists and religionists,

Address correspondence and reprint requests to: Effie Fokas, Grassrootsmobilise; Hellenic Foundation for European and Foreign Policy (ELIAMEP); Hellenic Observatory, London School of Economics, Vassilisis Sofias 49, Athens, 10676, Greece. E-mail: esfokas@eliamep.gr

*This text introduces a collection of articles emanating from the European Research Council-funded Grassrootsmobilise Research Programme (GA no. 338463; see www.grassrootsmobilise.eu), of which the author is principal investigator. 
between religious minorities and majorities, and amongst all of the above in increasingly complex constellations of actors and interests.

Across various country contexts we find in this domain a necessarily delicate balancing of conflicting interests. States waver between their commitment to abide by a number of human rights norms set out in international treaties and conventions, on the one hand, and on the other their drive to appease (or cultivate, as the case may be) national "emotional inheritances" (Asad 2006) firmly embedded in education systems. The reach of these inheritances goes well beyond the teaching, or not, of religion in schools (and the nature of such courses and conditions under and processes through which exemption can be achieved); it includes also the way religion is taught in history courses, for example, and the relative success of religious arguments in limiting sex education or the teaching of evolution, and the presence of religious symbols in schools. The management by governments of such issues within the educational arena may carry significant political repercussions; as Peter van der Veer notes, the location of religion in educating national subjects is a function of the location of religion in the imagination of the nation (Van der Veer 2011, 236).

States' obligations to conform to international human rights norms may also conflict with the perceived right of parents to "have the last say" about the religious and moral education of their children (Plesner 2004, 805). As Carolyn Evans explains, "to exclude religion from the curriculum is as offensive to one set of parents as including it is to another set" (Evans 2008, 458). Thus the field of religion and education is also especially emotive, evoking passionate statements about the vulnerability of "our youth", whether that vulnerability is expressed in terms of a feared indoctrination of students, or worries about discrimination against those who opt out of all things religious.

The place of religion in the educational arena has perhaps always been one of the more socially and politically volatile issues arising around religion in the public sphere (Evans 2008; Doe 2011), not least because of the traditionally critical role of the school in the inculcation of meaning (Ferrari 2014, 26) and in the formation of collective identity in the nation-state (Hunter-Henin 2012, 8; Seligman 2014, 1).

Today however, a combination of increasing religious diversity, globalization rendering local issues international and vice versa, and boundedness by international institutions and their accompanying regulatory frameworks, together form a challenging set of changing parameters within which various states must address and re-address questions to do with the proper place of religion in the educational arena. One such 
international institution, with a remit to adjudicate rights in the educational domain, is the European Court of Human Rights (ECtHR, or the Court).

Since as far back as 1976 the ECtHR ${ }^{1}$ has been addressing such issues as whether compulsory sex education entails a violation of the parents' right to education in accordance with their religious or philosophical beliefs (Kjeldsen versus Denmark). Since then, and now with potential effect upon 47 countries, ${ }^{2}$ the Court has considered an incredibly broad range of issues in over 50 cases relating somehow to religion and education, including but not limited to the conditions under which exemption from religious education may be secured (Bernard versus Luxembourg, 1993 and Zengin versus Turkey, 2007), the right to opt out of a school parade on religious grounds (Valsamis versus Greece, 1996), religious dress of teachers (Dahlab versus Switzerland, 2001) and of students (Sahin versus Turkey, 2005, Dogru and Kervanci versus France, 2008, and Singh versus France, 2008), specific content of the religious education course and extent to which an emphasis on the majority faith is legitimate (Folgero versus Norway, 2007), display of religious symbols in the classroom (Lautsi versus Italy, 2011), and the rights of the state in relation to the church in the employment of religious education teachers (Fernandez-Martinez versus Spain, 2014). Thus the ECtHR is clearly an active player in the European sphere in the rapidly broadening domain of religion and education (see Evans 2008; Hunter-Henin 2012; Leigh, 2012; Lozano 2013).

Certainly the potential policy impact of this large body of case law is momentous: though the Court's jurisprudence is continually evolving and religion-related issues tend to be subject to a variable margin of appreciation, important precedents have been set especially regarding the content of religious education courses, conditions for exemption, and the presence of religious symbols in the schools. The implementation, or non-implementation as the case may be, of the Court's decisions in various national contexts through policy change is a rather narrow research question when considered in relation to the far broader potential impact of courts (see Fokas 2015). As Marc Galanter notes, "courts resolve by authoritative disposition only a small fraction of all disputes that are brought to their attention. These are only a small fraction of all disputes that might conceivably be brought to court and an even smaller fraction of the whole universe of disputes" (Galanter 1983, 119). But the potential impact of courts on the "whole universe of disputes" is much broader, if one considers the "radiating effects" of courts (Fokas 2015). So too with the entire domain of religion and education: the potential effects of the 
Court radiate well beyond the resolution of particular issues at hand in each case.

This special issue is concerned with the far broader spectrum of indirect effects of the Court's jurisprudence to do with the place of religion in the educational sphere. ${ }^{3}$ It is this broader spectrum of the Court's influence that constitutes the "shadow" of the ECtHR. Examination of the less conspicuous but no less important domain of indirect effects yields critical insight into how the Court's decisions in the broad field of religion and education may influence related domestic debates, raise public consciousness, change how social actors perceive their rights and articulate their claims in this subject area, and thus provide the discursive frameworks and political opportunity structures within which citizens act in the area of religion and education.

The study of such indirect effects of courts is well-developed in the North American context (see indicatively, Galanter 1983; McCann 1994; 2004; Hoover and den Dulk 2004; Scheingold 2004; NeJaime 2011), but remains limited in relation to the ECtHR, ${ }^{4}$ whilst there is a complete lacuna in empirically-based qualitative study of the Court's indirect effects. ${ }^{5}$ Meanwhile, though research on religion and education in the European sphere is bountiful, scholarly attention specifically to the impact of the ECtHR is highly instructive but does not consider the indirect effects of the Court's related case law (Evans 2008; Doe 2011; HunterHenin 2012; Leigh 2012; Lozano 2013; Ferrari 2014). Thus the research underpinning this special issue represents a clear departure from existing scholarship on religion, education and the ECtHR: it examines the impact of the Court not from the top-down (Court impact on states and their legislative frameworks) but from grassroots level upwards, in seeking to understand whether, how and to what extent Court decisions influence grassroots level actors' conceptions of their rights in the domain of religion and education and their efforts to secure new rights vis-à-vis their states.

\section{INDIRECT EFFECTS AT THE GRASSROOTS LEVEL IN FOUR COUNTRY CONTEXTS}

A great deal of a court's influence is enacted through transmission and reception of information, rather than by concrete imposition of policy changes through judgments issued. As Galanter explains, "Courts produce not only decisions, but messages. These messages are resources 
that parties use in envisioning, devising, pursuing, negotiating, vindicating claims (and in avoiding, defending, and defeating them)" (Galanter 1983, 126; see also Fokas 2015). The impact of these messages is largely contingent on how these messages are received by social actors on the ground, and on their capacities for evaluating, processing, and using the information contained in those messages. Thus, one may take for granted variations in reception of the message: "a single judicial action may radiate different messages to different audiences' (Galanter 1983, 126). Likewise, there is always potential for inaccuracy in the transmission of the message; and the competing messages already present in the space where the new, court-originated messages land must also be considered (Galanter 1983; see also Fokas 2015)."

Thus any study of the indirect effects of courts, and specifically in the European context, requires contextualization and, ideally for our present purposes, national and local case study based approaches to the impact of the ECtHR religious freedoms case law on religious pluralism at the grassroots level. It is at this level that we can best detect not only indirect but also unexpected and/or counterproductive effects of the Court's decisions.

Here we see a malleability of the case law, a sense in which the impact of the case law at the grassroots level is contingent on "the eye of the beholder'. From this we may conclude that a fuller understanding of the ECtHR's impact on religious pluralism requires insight into the extent to which its case law is known in the first place, at the grassroots level, and the various ways that case law may be adapted within given national and cultural contexts. This perspective significantly multiplies the potential effects of the very same ECtHR actions and decisions."

Certainly the debates arising in different country contexts are highly contingent on the relevant conditions, the "starting point", so to speak, of the place of religion in the educational arena in the given context. For example, in Ireland, a human rights frame is used to challenge the "integrated curriculum" whereby schools are legally obliged "to ensure that a religious spirit informs and vivifies the whole work of the school" (Mawhinney 2007, 379), whilst in the UK the British Humanist Association has been engaged in an effort to extend the content of religious education to include non-religious world views (Barnes 2015); the resonances of the ECtHR case law on religion and education will differ significantly from one context to the other. Thus, precisely because judicially articulated legal norms take a life of their own when deployed in social actions in various contexts (McCann 1994, 733), the approach 
must be highly contextualized, sensitive to the variable effects on different types of actors and to changes in the latter over time (Berger 2014), in multiple venues and contexts, and in different country (i.e., national, cultural, and religious) cases.

The articles in the present collection draw on in-depth qualitative field research conducted in the area of religion and education in four particular country contexts-Greece, Italy, Romania, and Turkey - and engaging a broad range of social actors, including religious minority actors; religious majority actors; representatives of secular, religious, and other ideological NGOs; "cause lawyers" representing religious freedoms cases; and state representatives dealing with religious freedoms issues. A red thread running throughout these case studies is what is the ECtHR impact on grassroots level engagements with religion and education (whether much or little, direct or indirect, limited to certain groups or certain time periods, etc.)? In some cases we are also offered insight into why the ECtHR impact is such that it is.

These particular countries are selected as case studies because they represent contexts in which religion is particularly significant from a social, cultural, and political perspective. In each of these countries, a strong relationship between religion and national identity, and church and state renders highly salient, in theory at least, the Court's religion-related case law which carries the potential to influence the public place of religion in general and in the educational arena in particular. Accordingly, in these country contexts a broad range of religious, social, and political actors may be expected to perceive the stakes of the religion-related ECtHR case law as relatively high (see also Fokas 2015).

Meanwhile the selection of cases represents a spectrum of levels of democratization and Europeanization, with Italy and Greece being rather more consolidated democracies (and with membership in the European unification project established in 1958 and 1981, respectively), and Romania and Turkey less consolidated democracies (and with more recent membership in the EU for Romania in 2007 and a continued negotiation process with Turkey). The present collection of articles helps identify the significance of each of these dimensions when it comes to the impact of the ECtHR on the ground in various country contexts, each of which has, in recent years, seen mobilizations around the topic of religion and education, often using a human rights frame and in some cases with specific references to the ECtHR.

Collectively these articles push the boundaries of our understanding of the Court's impact on religion and education, but also more generally 
about the Court's influence on religious pluralism and Court influence on human rights overall. As exhibited through these case study examples, the field of religious education serves as a locale for secular versus religious debates, as well as for the management of religious minority versus majority rights. Careful attention to both dimensions allows the generation of new insights regarding the centrality of the educational arena in the management of religious pluralism in Europe.

\section{NOTES}

The author would like to acknowledge the support of the European Research Council (GA no 338463), under the auspices of which the research showcased in this volume was conducted. I would also like to acknowledge the support of the Hellenic Observatory of the London School of Economics, where my research associateship has further supported our work in Grassrootsmobilise. Thanks are also due, on behalf of all the Grassrootsmobilise research team, to the scholars who joined us in a meeting in Istanbul in November of 2015 to discuss our research on religion and education: Dr. Katayoun Alidadi, Professor Marie-Claire Foblets, Professor Haldun Gulalp, Professor Javier Martinez-Torron, Dr. Jeroen Temperman, Dr. Riza Turmen, and Professsor Marco Ventura. Their feedback on our research and early drafts of the texts presented in this symposium on religion and education was invaluable.

1. Or the Commission on Human Rights which preceded it in this role until 1998.

2. The Court covers the 47 member states of the Council of Europe, which are also signatories to the European Convention on Human Rights that the Court defends.

3. For a collection of articles examining the indirect effects of European Court of Human Rights case law on the legal status of religious minorities, please see Religion, State and Society, 2017, Vol. 45, Nos. 3-4.

4. Cichowski (2007); Richardson and Lee (2014); Voeten (2013). Of course, comparatively speaking, a well-established history of rights consciousness raising has developed around the US Supreme Court.

5. Çali, Koch and Bruch (2013) explore conceptions of ECtHR legitimacy amongst political leaders, lawyers and judges in Turkey, the UK, Ireland, Germany and Bulgaria; their focus is general (i.e. not specifically on religion and/or religious education), and their study does not include attention to grassroots level social actors. See Fokas 2015 for a fuller explanation of the gap in scholarship filled by the research underpinning this collection of articles.

\section{REFERENCES}

Asad, Talal. 2006. "French Secularism and the "Islamic Veil Affair"'. The Hedgehog Review 8(1/2): 93-106.

Barnes, Philip. 2015. "Humanism, Non-Religious Worldviews and the Future of Religious Education". Journal of Beliefs and Values 36(1): 79-91.

Berger, Benjamin. 2014. "Religious Diversity, Education and the 'Crisis' in State Neutrality". Canadian Journal of Law and Society 29(1): 103-122.

Çali, Başak, Anne Koch, and Nicola Bruch. 2013. "The Legitimacy of Human Rights Courts: A Grounded Interpretivist Analysis of the European Court of Human Rights". Human Rights Quarterly 35(4): 955-984.

Cichowski, Rachel. 2007. The European Court and Civil Society - Litigation, Mobilization and Governance. Cambridge: Cambridge University Press.

Doe, Norman. 2011. Law and Religion in Europe: A Comparative Introduction. Oxford: Oxford University Press. 
Evans, Carolyn. 2008. "Religious Education in Public Schools: An International Human Rights Perspective". Human Rights Law Review 8(3): 449-473.

Ferrari, Silvio. 2014. "Teaching Religion in the European Union: A Legal Overview". In Religious Education and the Challenge of Pluralism, ed. Adam B. Seligman. Oxford: Oxford University Press, 25-44.

Fokas, Effie. 2015. "Directions in Religious Pluralism in Europe: Mobilizations in the Shadow of European Court of Human Rights Religious Freedom Jurisprudence". Oxford Journal of Law and Religion 4(1): 54-74.

Galanter, Marc. 1983. "The Radiating Effects of Courts". In Empirical Theories About Courts, eds. Keith O. Boyum and Lynn M. Mather. New York: Longman, 117-142.

Hoover, Dennis, and Kevin R. den Dulk. 2004. "Christian Conservatives Go to Court: Religion and Legal Mobilization in the United States and Canada". International Political Science Review 25(1): 9-34.

Hunter-Henin, Myriam. 2012. "Religious Freedoms in European Schools: Contrasts and Convergences". In Laws, Religious Freedoms and Education in Europe, ed. Myriam Hunter-Henin. Farnham: Ashgate, 1-33.

Leigh, Ian. 2012. "Objective, Critical and Pluralistic? Religious Education and Human Rights in the European Public Sphere". In Law, State and Religion in the New European Union, eds. Lorenzo Zucca and Camil Ungureanu. Cambridge: Cambridge University Press, 192-214.

Lozano, Rafael P. 2013. "Religion and Education in the Council of Europe: Toward A "Soft" Constitutionalization of A Model of Religious Teaching?". In Law, Religion, Constitution: Freedom of Religion, Equal Treatment, and the Law, eds. W. Cole Durham Jr., Silvio Ferrari, Cristiana Cianitto and Donlu Thayer. Farnham: Ashgate, 369-384.

Mawhinney, Alison. 2007. "Freedom of Religion in the Irish Primary School System: A Failure to Protect Human Rights?". Legal Studies. 27(3): 379-403.

McCann, Michael. 1994. Rights at Work. Chicago: University of Chicago Press.

McCann, Michael. 2004. "Law and Social Movements". In Blackwell Companion to Law and Society, ed. Austin Sarat. Oxford: Blackwell, 506-522.

NeJaime, Douglas. 2011. "Winning Through Losing”. Iowa Law Review. 96(March): 9411012.

Plesner, Ingvill Thorson. 2004. "Promoting Tolerance Through Religious Education". In Facilitating Freedom of Religion or Belief: A Deskbook, eds. Tore Lindholm, W. Cole Durham Jr. and Bahia G. Tahzib-Lie. Leiden: Nijhoff, 791-812.

Richardson, James, and Brian Lee. 2014. "The Role of the Courts in the Social Construction of Religious Freedom in Central and Eastern Europe". Review of Central and East European Law 39(3-4): 291-313.

Scheingold, Stuart A. 2004. The Politics of Rights - Lawyers, Public Policy, and Political Change, 2nd edition. Ann Arbor: University of Michigan Press.

Seligman, Adam B. 2014. "Living Together Differently, Education and the Challenge of Deep Pluralism". In Religious Education and the Challenge of Pluralism, ed. Adam B. Seligman. Oxford: Oxford University Press, 1-24.

Van der Veer, Peter. 2011. "Religion and Education in A Secular Age: A Comparative Perspective". Extrême-Orient Extrême-Occicent 33(1): 235-245.

Voeten, Erik. 2013. "Public Opinion and the Legitimacy of International Courts". Theoretical Inquiries in Law 14(2): 411-436. 